\title{
Model Kemitraan dalam Penyusunan Daftar Informasi Publik di PPID Utama Kabupaten Aceh Barat
}

\author{
Afrizal Tjoetra ${ }^{1}$ \\ Universitas Teuku Umar, afrizaltjoetra@utu.ac.id \\ Nodi Marefanda ${ }^{2}$ \\ Universitas Teuku Umar, nodimarefanda@utu.ac.id \\ Irsadi Aristora ${ }^{3}$ \\ Universitas Teuku Umar, irsadiaristora@utu.ac.ic \\ Sudarman ${ }^{4}$ \\ Universitas Teuku Umar, sudarman@utu.ac.id
}

\begin{abstract}
Abstrak
Hak atas informasi publik dijamin oleh negara. Namun, pengelolaan informasi publik di Kabupaten Aceh Barat belum berjalan sesuai amanat Undang-Undang Keterbukaan Informasi Publik. Hal ini dikarenakan masih terbatasnya pengetahuan dan keterampilan sumber daya aparatur pemerintahan dalam pelaksanaan ketentuan undang-undang dimaksud. Untuk itu, pelaksanaan pengabdian menjadi penting untuk percepatan layanan informasi publik di Aceh Barat. Tujuan umum pengabdian untuk meningkatkan kepatuhan badan publik Pemerintah di Kabupaten Aceh Barat dalam melaksanakan UU KIP. Sedangkan tujuan khususnya terdiri tiga bagian, yaitu menyampaikan umpan balik temuan pengabdian kepada badan publik Pemerintah Kabupaten Aceh Barat, meningkatkan kesiapan badan publik Pemerintah di Kabupaten Aceh Barat dalam melaksanakan UU KIP melalui penyusunan daftar informasi publik, serta meningkatkan layanan informasi publik di Pemerintah Kabupaten Aceh Barat dalam menyediakan dan mengumumkan informasi berkala, informasi yang tersedia setiap saat dan informasi serta merata. Pengabdian dilakukan melalui empat tahap, yakni melalui pertemuan awal dengan Sekretaris Daerah Aceh Barat selaku Atasan Pejabat Pengelola Informasi dan Dokumentasi Utama dan PPID Utama Kabupaten Aceh Barat, sosialisasi hasil pengabdian, workshop penyusunan daftar informasi publik, serta pendampingan dalam penyusunan daftar informasi publik. Berdasarkan pengabdian terhadap PPID Utama dan PPID Pembantu diperoleh bahwa proses koordinasi antara Tim Pertimbangan dan PPID Utama Kabupaten Aceh Barat menjadi penting dan strategis. Berikutnya, proses pendampingan telah menghasilkan daftar informasi publik PPID Utama dan PPID Pembantu di Kabupaten Aceh Barat, serta adanya kerja sama antara perguruan tinggi, OMS (MaTA), PPID Utama Aceh, dan PPID Utama Kabupaten Aceh Barat semakin mempercepat proses penyusunan daftar informasi publik

Kata Kunci: Informasi Publik, Pejabat Pengelola Informasi dan Dokumentasi, Badan Publik, Daftar Informasi Publik, Layanan Informasi Publik, Kabupaten Aceh Barat.
\end{abstract}

\begin{abstract}
The right to public information is guaranteed by the state. However, the management of public information in Aceh Barat Regency has not yet proceeded as mandated by the Public Information Disclosure Act. This is due to the limited knowledge and skills of the government apparatus in implementing the provisions of the law. For this reason, the implementation of service is important for the acceleration of public information services in Aceh Barat. The general purpose of service is to improve the compliance of the Government's public bodies in Aceh Barat District in implementing the KIP Law. Whereas the specific objective consists of three parts, namely conveying research findings feedback to the Aceh Barat District Government public body, increasing the readiness of the
\end{abstract}


Jurnal Pengabdian Kepada Masyarakat

Government public body in Aceh Barat Regency in implementing the KIP Law through the compilation of public information lists, and improving public information services in the Aceh Barat District Government in providing and announcing periodic information, information available at all times and information and evenly distributed. Dedication is carried out through four stages, namely through an initial meeting with the Secretary of Aceh Barat as the Chief Management Officer of Main Information and Documentation and the Main PPID of Aceh Barat Regency, socializing the results of the research, workshop on compiling a list of public information, and mentoring in preparing a list of public information. Based on the dedication of the Main PPID and the Assistant PPID, it was found that the coordination process between the Aceh Barat District Consideration Team and the Main PPID was important and strategic. Next, the mentoring process has produced a public information list of the Main PPID and Assistant PPID in Aceh Barat District, as well as the collaboration between universities, OMS (MaTA), Aceh Primary PPIDs, and the Main PPID of Aceh Barat Regency to accelerate the process of compiling public information lists

Keywords: Public Information, Information and Documentation Management Officer, Public Agency, List of Public Information, Public Information Services, Aceh Barat Regency

\section{Pendahuluan}

Upaya Pemerintah Indonesia untuk menjalankan good governance and clean governance semakin nyata. Hal ini dikuatkan dengan disahkannya Undang-undang Keterbukaan Informasi Publik (UU KIP) pada 30 April 2008 lalu. Mengingat, keterbukaan informasi publik menjadi keharusan agar pelaksanaan pemerintahan yang baik dan bersih dapat berlangsung. Selain itu, partisipasi publik dalam seluruh proses pemerintahan diharapkan semakin meningkat pasca reformasi untuk memastikan perubahan tetap berlangsung di Nusantara.

Hak atas Informasi menjadi sangat penting karena makin terbuka penyelenggaraan negara untuk diawasi publik, penyelenggaraan negara tersebut semakin dapat dipertanggungjawabkan. Hak setiap Orang untuk memperoleh informasi juga relevan untuk meningkatkan kualitas pelibatan masyarakat dalam proses pengambilan keputusan publik. Partisipasi atau pelibatan masyarakat tidak banyak berarti tanpa jaminan keterbukaan Informasi Publik (Penjelasan umum UU KIP).

Penguatan keterbukaan informasi publik menjadi komitmen yang ditunjukkan Pemerintahan di Aceh dan Pemerintahan Kabupaten/Kota. Hal ini dilaksanakan dengan membentuk Pejabat Pengelola Informasi dan Dokumentasi (PPID) Utama dan Pembantu pada Satuan Kerja Perangkat Aceh (SKPA). Penunjukan ini dilakukan melalui Surat Keputusan Gubernur Aceh Nomor 480/335/2012. Selanjutnya, Pemerintah Aceh juga membentuk Peraturan tentang Pedoman Pengelolaan Informasi dan Dokumentasi untuk PPID melalui Peraturan Gubernur Aceh Nomor 39 Tahun 2012. Berikutnya, Pemerintah Aceh membentuk Komisi Informasi Aceh (KIA) pada 19 Juni 2012, dengan SK Gubernur Aceh Nomor 555/389/2012 sebagai pelaksanaan UU KIP (Afrizal \& Sudarman, 2017)

Berikutnya, berdasarkan pengabdian yang dilakukan (Afrizal \& Sudarman, 2017) tentang kepatuhan badan publik di Kabupaten Aceh Barat 2016 lalu, juga diketahui sejumlah hambatan dalam melaksanakan UU KIP, antara lain: 
1. Kepatuhan PPID Pembantu di Aceh Barat dalam melaksanakan UU KIP masih kurang.

Secara umum nilai gabungan masih dibawah $50 \%$, bermakna masih terdapat informasi publik belum diumumkan, disediakan dan termasuk belum maksimalnya penyediaan sarana pendukung pelayanan informasi publik di Aceh Barat.

2. Sejumlah faktor yang memengaruhi kepatuhan aparatur Pemerintahan di Kabupaten Aceh Barat dalam melaksanakan UU KIP, antara lain :

a. Pentingnya koordinasi antar penentu kebijakan (Bupati, Sekda, dan PPID Utama) sangat membantu percepatan pelaksanaan UU KIP di Aceh Barat.

b. Penyediaan sumber daya manusia yang handal dengan jumlah yang cukup sangat membantu kepatuhan badan publik melaksanakan UU KIP.

c. Dukungan pendanaan serta pendukung kerja lainnya sangat membantu upaya pelaksanaan UU KIP di Aceh Barat.

d. Perubahan perilaku dan budaya aparatur pemerintahan di Aceh Barat, terutama PPID Pembantu SKPK dalam melaksanakan layanan informasi publik

e. Selain itu, partisipasi publik melalui uji akses tentang layanan informasi yang diperlukan juga menjadi faktor yang berpengaruh untuk meningkatkan layanan aparatur pemerintahan di Aceh Barat.

Berdasarkan uraian tersebut, pendampingan melalui pengabdian dilaksanakan untuk memastikan badan publik melaksanakan UU KIP di Kabupaten Aceh Barat. Proses pendampingan secara khusus mendorong dibentuknya daftar informasi publik dengan dukungan unsur pemerintahan Kabupaten Aceh Barat, Dinas Komunikasi, Informatika, dan Persandian Aceh serta Universitas Teuku Umar dan Organisasi Masyarakat Sipil. Proses kemitraan yang dilakukan menjadi bagian penting dan strategis untuk mempercepat lahirnya daftar informasi publik sebagai bagian penting melaksanakan layanan informasi publik di Aceh Barat.

\section{Tujuan Pengabdian}

a. Meningkatkan kepatuhan Badan Publik Pemerintah di Kabupaten Aceh dalam melaksanakan UU KIP;

b. Menyampaikan umpan balik kepada badan publik Pemerintah Kabupaten Aceh Barat berdasarkan hasil penelitian, sehingga adanya penguatan terhadap PPID Utama dan PPID Pembantu di Kabupaten Aceh Barat;

c. Meningkatkan kesiapan badan publik Pemerintah di Kabupaten Aceh Barat dalam melaksanakan UU KIP melalui penyusunan daftar informasi publik; dan

d. Meningkatkan layanan informasi publik di Pemerintah Kabupaten Aceh Barat dalam menyediakan dan mengumumkan informasi berkala, informasi yang tersedia setiap saat dan informasi serta-merta.

\section{Manfaat Pengabdian}

a. Dapat memperbaiki dan meningkatkan kesiapan badan publik Pemerintah di Kabupaten Aceh Barat dalam melaksanakan UU KIP melalui penyusunan daftar informasi publik; dan 
b. Sebagai masukan untuk memperbaiki layanan informasi publik di Pemerintah Kabupaten Aceh Barat dalam menyediakan dan mengumumkan informasi berkala, informasi yang tersedia setiap saat dan informasi serta-merta.

\section{Konsep Kemitraan}

Merujuk (Sulistyani, 2004) bahwa kemitraan dilihat dari perspektif etimologis diadaptasi dari kata partnership, dan berasal dari akar kata partner. Partner dapat diterjemahkan "pasangan, jodoh, sekutu, atau kampanyon". Makna partnership yang diterjemahkan menjadi persekutuan atau perkongsian. Dengan kandungan makna tersebut maka kemitraan dapat dipahami sebagai bentuk persekutuan antara dua pihak atau lebih yang membentuk suatu ikatan kerja sama atas dasar kesepakatan dan rasa saling membutuhkan dalam rangka meningkatkan kapasitas dan kapabilitas untuk agenda tertentu guna memperoleh capaian yang disepakati. Sedangkan Kamus Besar Bahasa Indonesia menerangkan bahwa kata mitra adalah teman, kawan kerja, rekan. Sementara kemitraan artinya perihal hubungan atau jalinan kerja sama sebagai mitra.

Cakupan kemitraan yang dimaksud dalam penulisan ini terkait dengan kemitraan yang terbangun antara Pemerintah Kabupaten Aceh Barat melalui Dinas Komunikasi dan Informatika Kabupaten Aceh Barat, Organisasi Nonpemerintah melalui Masyarakat Transparansi Aceh (MaTA), serta Universitas Teuku Umar melalui Tim Pengabdian Badan Publik Pemerintahan Kabupaten Aceh Barat. Kemitraan yang dimaksud terkait jalinan kerja sama yang terjadi antar institusi dalam kegiatan penyusunan daftar informasi publik pada PPID Utama dan PPID Pembantu Kabupaten Aceh Barat.

\section{Pola Kemitraan}

Menurut (Wibisono, 2007) bahwa kemitraan yang dilakukan antara perusahaan dengan pemerintah maupun komunitas/masyarakat dapat mengarah pada tiga pola, diantaranya:

\section{Pola kemitraan kontra produktif}

Pola ini akan terjadi jika perusahaan masih berpijak pada pola konvensional yang hanya mengutamakan kepentingan shareholders yaitu mengejar profit sebesarbesarnya. Fokus perhatian perusahaan memang lebih bertumpu pada bagaimana perusahaan bisa meraup keuntungan secara maksimal, sementara hubungan dengan pemerintah dan komunitas atau masyarakat hanya sekedar pemanis belaka. Perusahaan berjalan dengan targetnya sendiri, pemerintah juga tidak ambil peduli, sedangkan masyarakat tidak memiliki akses apapun kepada perusahaan. Hubungan ini hanya menguntungkan beberapa oknum saja, misalnya oknum aparat pemerintah atau preman di tengah masyarakat. Biasanya, biaya yang dikeluarkan oleh perusahaan hanyalah digunakan untuk memelihara orang-orang tertentu saja. Hal ini dipahami, bahwa bagi perusahaan yang penting adalah keamanan dalam jangka pendek.

\section{Pola Kemitraan Semi Produktif}


Dalam skenario ini pemerintah dan komunitas atau masyarakat dianggap sebagai obyek dan masalah diluar perusahaan. Perusahaan tidak tahu program-program pemerintah, pemerintah juga tidak memberikan iklim yang kondusif kepada dunia usaha dan masyarakat bersifat pasif. Pola kemitraan ini masih mengacu pada kepentingan jangka pendek dan belum atau tidak menimbulkan sense of belonging di pihak masyarakat dan low benefit dipihak pemerintah. Kerjasama lebih mengedepankan aspek karitatif atau public relation, dimana pemerintah dan komunitas atau masyarakat masih lebih dianggap sebagai objek. Dengan kata lain, kemitraan masih belum strategis dan masih mengedepankan kepentingan sendiri (self interest) perusahaan, bukan kepentingan bersama (commont interest) antara perusahaan dengan mitranya.

\section{Pola Kemitraan Produktif}

Pola kemitraan ini menempatkan mitra sebagai subyek dan dalam paradigma commont interest. Prinsip simbiosis mutualisme sangat kental pada pola ini. Perusahaan mempunyai kepedulian sosial dan lingkungan yang tinggi, pemerintah memberikan iklim yang kondusif bagi dunia usaha dan masyarakat memberikan dukungan positif kepada perusahaan. Bahkan bisa jadi mitra dilibatkan pada pola hubungan resourced based patnership, dimana mitra diberi kesempatan menjadi bagian dari shareholders. Sebagai contoh, mitra memperoleh saham melalui stock ownership Program.

\section{Pemerintah Daerah}

\section{Konsep pemerintahan daerah}

Sesuai Pasal 1 Undang-Undang Nomor 32 Tahun 2004 Tentang Pemerintahan Daerah menyebutkan: Pemerintah Daerah adalah Gubernur, Bupati, atau Walikota dan perangkatnya sebagai unsur penyelenggara Pemerintah Daerah. Penyelenggaraan urusan pemerintah oleh Pemerintah Daerah dan DPRD menurut asas otonomi dan tugas pembantuan dengan prinsip otonomi seluas-luasnya dalam sistem dan prinsip Negara Kesatuan Republik Indonesia sebagaimana dimaksud dalam Undang-Undang Dasar Negara Republik Indonesia

\section{Asas Penyelenggaraan Pemerintah Daerah}

Menurut Pasal 20 Ayat 2 Undang-Undang No. 32 Tahun 2004, terdapat tiga asas penyelenggaraan pemerintahan daerah, yaitu:

1. Asas desentralisasi, yaitu penyerahan wewenang pemerintahan oleh Pemerintah daerah kepada daerah otonom untuk mengatur dan mengurus urusan pemerintahan dalam sistem Negara Kesatuan

Republik Indonesia;

2. Asas tugas pembantuan, yaitu penugasan dari Pemerintah kepada daerah dan/atau desa dari Pemerintah Provinsi kepada Pemerintah Kabupaten/Kota dan/atau desa serta dari Pemerintah Kabupaten/Kota kepada desa untuk melakukan tugas tertentu;

3. Asas dekonsentrasi, yaitu pelimpahan wewenang pemerintahan oleh Pemerintah kepada Gubernur sebagai wakil Pemerintah dan/atau kepada instansi vertikal di wilayah tertentu. 


\section{Metode}

Pengabdian ini menggunakan pendekatan metode pelatihan dengan sumber utama proses dan informasi tentang pengabdian terhadap badan publik dalam pembentukan daftar informasi publik di Kabupaten Aceh Barat. Secara umum, terdapat empat konsep yang dijadikan sebagai landasan untuk membangun model kemitraan dalam penyusunan daftar informasi publik, yaitu kemitraan, pemerintah daerah, perguruan tinggi, serta organisasi masyarakat sipil.

Metode yang digunakan dalam pelaksanaan pengabdian tersebut adalah: Melakukan sosialisasi kepada PPID utama dan PPID Pembantu di Kabupaten Aceh Barat serta perwakilan MaTA, Tahap Perumusan Daftar Informasi Publik melalui kegiatan workshop sebanyak dan focus group discussion (FGD) serta rapat koordinasi tim pengabdian.

\section{Hasil Dan Pembahasan}

Sesuai dengan laporan pengabdian Tim Pendampingan Badan Publik di Kabupaten Aceh Barat, diketahui bahwa pengabdian dilakukan melalui 3 (tiga) tahapan, yaitu:

1. Tahap Pertama

Tahap pertama dilaksanakan melalui pertemuan dengan penentu kebijakan di Aceh Barat, yaitu Sekda selaku Atasan PPID Utama dan PPID Utama Kabupaten Aceh Barat. Tahap ini menjadi penting agar seluruh agenda yang dilaksanakan mendapatkan kelancaran dan kemudahan dari penentu kebijakan karena seluruh rangkaian kegiatan melibatkan PPID Pembantu dari SKPK di Kabupaten Aceh Barat. Selain itu, pertemuan dengan penentu kebijakan untuk memastikan komitmen dan dukungan terhadap pelaksanaan UU KIP di Aceh Barat. Rapat koordinasi sebelum pelaksanaan pengabdian dapat dilihat pada Gambar 1 dan 2

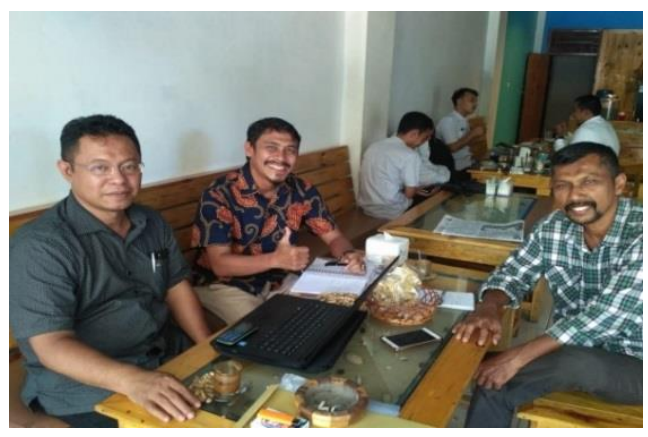

Gambar 1 Rapat Koordinasi antara Tim Pengabdian, Kominfo Aceh Barat, dan MaTA

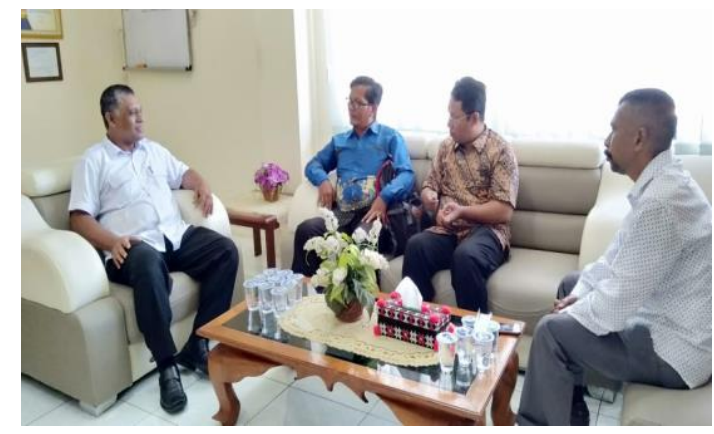

Gambar 2 Koordinasi dengan Sekda Aceh Barat

\section{Tahap Sosialisasi}

Tahap sosialisasi merupakan tahap pemantapan gagasan dan dukungan dari PPID Utama dan PPID Pembantu di Aceh Barat. Pelaksana pengabdian menyampaikan hasil-hasil yang diperoleh selama penelitian terkait dengan kepatuhan badan publik pemerintah Aceh Barat dalam melaksanakan UU KIP, termasuk pengelolaan dan pelayanan informasi publik. Tahapan ini juga menjadi penting sebagai wujud dari tri 
Jurnal Pengabdian Kepada Masyarakat

dharma Perguruan Tinggi terhadap berbagai agenda perubahan yang terjadi maupun yang hendak didukung dalam masyarakat, pemerintah, maupun pelaku usaha. Berikut disajikan pada Gambar 3 dan 4 dokumentasi pada saat sosialisasi tentang PPID

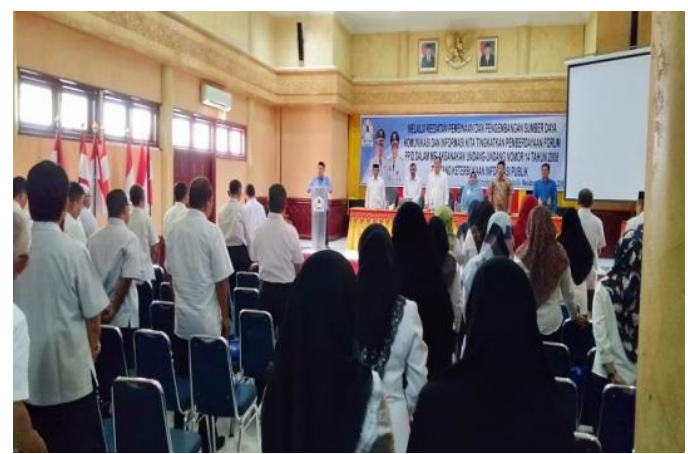

Gambar 3 Pelaksanaan Sosialisasi terkait dengan Penguatan PPID Lingkup Aceh Barat

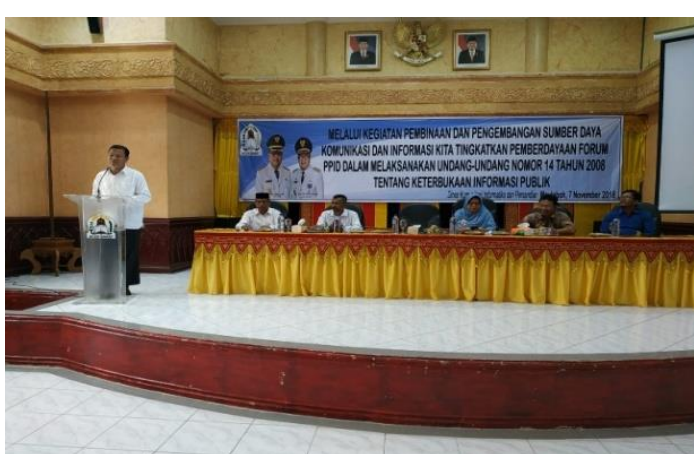

Gambar 4 Saat pembukaan kegiatan sosialisasi tentang PPID Lingkup Aceh Barat

3. Tahap Perumusan Daftar Informasi Publik

Tahap ketiga dilaksanakan dengan dua kegiatan, yaitu workshop dan FGD untuk perumusan draf daftar informasi publik. Pelaksanaan workshop diikuti oleh PPID Utama dan peserta dari PPID Pembantu badan publik Kabupaten Aceh Barat. Pelaksana pendampingan berperan sebagai narasumber dan fasilitator selama pelaksanaan workshop.

Perumusan draf daftar informasi publik dilakukan secara bersama antara PPID Utama dan PPID Pembantu. Pelaksana pengabdian berperan sebagai pendamping dan memfasilitasi melalui diskusi selama proses penyusunan daftar informasi publik. Berikut disajikan pada gambar 5 dan 6 dokumentasi pada saat sosialisasi tentang PPID

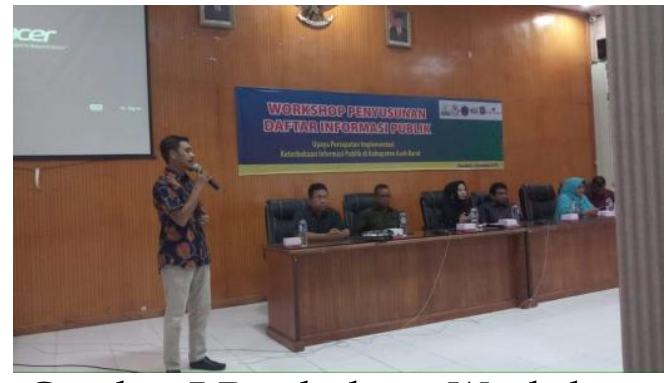

Gambar 5 Pembukaan Workshop Penyusunan DIP, 8 November 2018

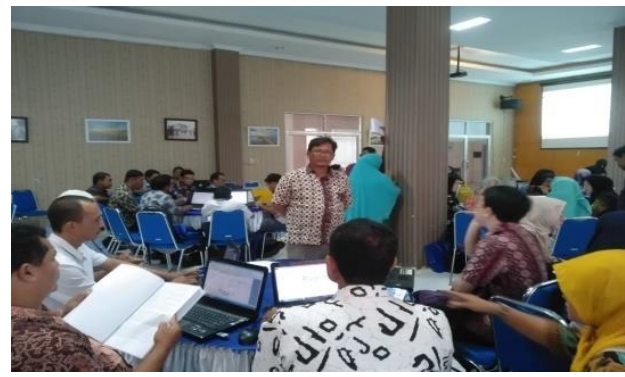

Gambar 6 Pendampingan saat pelaksanaan Workshop Penyusunan DIP

Kegiatan selanjutnya yaitu pelaksanaan focus group discussion (FGD). Kegiatan ini dihadiri oleh Tim Pertimbangan dan PPID Utama Kabupaten Aceh Barat serta Tim Pengabdian UTU, PPID Utama Aceh, serta MaTA. FGD dipimpin oleh Asisten I (Meurah Ali) Setdakab Aceh Barat dengan agenda pembahasan draf awal daftar informasi publik. PPID Utama menyampaikan hasil yang diperoleh saat workshop pertama dan mengharapkan dukungan Tim Perimbangan agar proses konsultasi 
internal dapat berlangsung sesuai harapan. Berikut disajikan pada Gambar 7 dan 8 dokumentasi FGD
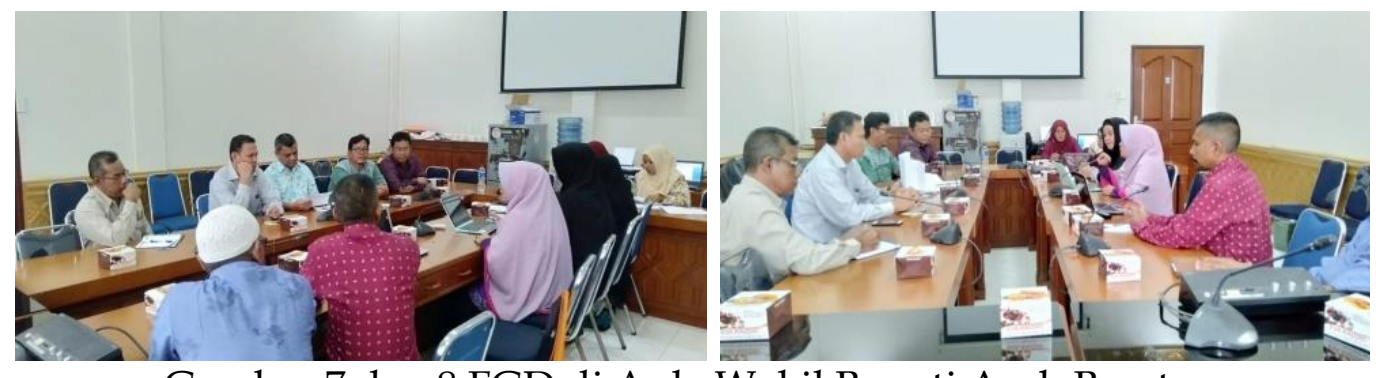

Gambar 7 dan 8 FGD di Aula Wakil Bupati Aceh Barat

Menindaklanjuti harapan PPID Utama Kabupaten Aceh Barat, Asisten I memerintahkan Kepala Dinas Komunikasi dan Informatika selaku PPID Utama untuk mengagendakan koordinasi antar pimpinan SKPK. Kegiatan koordinasi antar pimpinan SKPK telah berlangsung di Aula Bupati Aceh Barat yang juga dihadiri oleh Tim Pengabdian UTU. Berikut disajikan pada gambar 9 dan 10 dokumentasi pada FGD
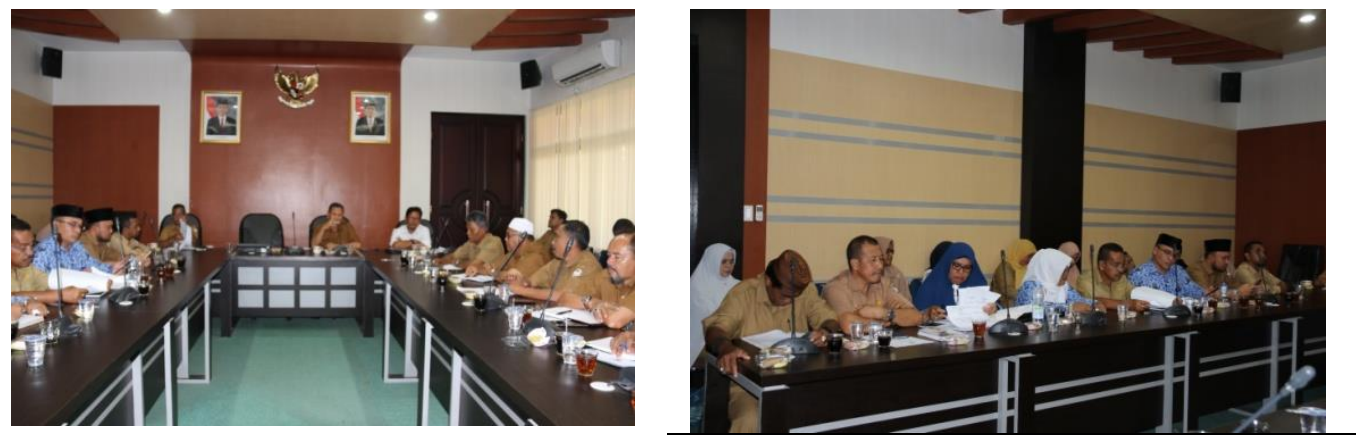

Gambar 9 dan 10 Pimpinan SKPK Aceh Barat koordinasi dengan tim pengabdian UTU di Aula Bupati Aceh Barat

Berdasarkan jenis kegiatan dan tahapan pelaksanaan di atas, dapat disampaikan bahwa: Tim Pengabdian telah melaksanakan rapat koordinasi pada tanggal 24 Oktober 2018 dengan PPID Utama Aceh Barat (Dinas Komunikasi dan Informatika Kabupaten Aceh Barat), MaTA (Organisasi Non Pemerintah-Ornop), serta PPID Utama Aceh. Pertemuan ini menghasilkan kesepakatan tentang sejumlah rangkaian kegiatan yang dilakukan secara bersama, sesuai dengan jenis dan dukungan kegiatan untuk menghasilkan daftar informasi publik.

Merujuk hasil diskusi dan pembahasan bersama, disepakati hal-hal sebagai berikut:

1. Pendampingan PPID Utama Kabupaten Aceh Barat dilakukan secara bersama antara PPID Utama Aceh, Pemkab Aceh Barat (Dinas Komunikasi dan Informatika), MaTA dan Tim Pengabdian UTU.

2. Kesepakatan kerjasama bertujuan untuk melahirkan SK dan DIP Pemkab Aceh Barat.

3. Pelaksanaan kegiatan bersama dapat dilihat pada tabel 1.1 berikut: 
Tabel 1 Pelaksanaan Kegiatan Bersama

\begin{tabular}{|c|c|c|c|c|}
\hline No. & $\begin{array}{c}\text { Uraian } \\
\text { Kegiatan }\end{array}$ & Tanggal & $\begin{array}{c}\text { Sumber } \\
\text { Dana }\end{array}$ & Keterangan \\
\hline \multirow[t]{2}{*}{1.} & \multirow[t]{2}{*}{$\begin{array}{l}\text { Sosialisasi } \\
\text { PPID dan } \\
\text { Workshop } \\
\text { Penyusunan } \\
\text { DIP Aceh } \\
\text { Barat }\end{array}$} & $\begin{array}{l}7 \text { November } \\
2018\end{array}$ & $\begin{array}{l}\text { Pemkab } \\
\text { Aceh } \\
\text { Barat }\end{array}$ & $\begin{array}{l}\text { Tema: } \\
\text { Sosialisasi PPID dan Workshop } \\
\text { Penyusunan DIP Bagi SKPK } \\
\text { Lingkup Kabupaten Aceh Barat, } \\
\text { dengan logo bersama antara } \\
\text { Pemprov, Pemkab, UTU, MaTA, } \\
\text { dan TAF }\end{array}$ \\
\hline & & $\begin{array}{l}8 \text { November } \\
2018\end{array}$ & MaTA & \\
\hline 2. & $\begin{array}{l}\text { FGD } \\
\text { (pembagian } \\
\text { tugas Tim } \\
\text { PPID Utama } \\
\text { Aceh Barat) }\end{array}$ & $\begin{array}{l}9 \text { November } \\
2018\end{array}$ & $\begin{array}{l}\text { Tim } \\
\text { Pengab } \\
\text { dian } \\
\text { UTU }\end{array}$ & $\begin{array}{l}\text { Peserta Tim Pertimbangan PPID } \\
\text { Utama Aceh Barat (kegiatan } \\
\text { dilaksanakan sebelum Jumat) }\end{array}$ \\
\hline 3. & $\begin{array}{l}\text { Workshop } \\
\text { Finalisasi DIP } \\
\text { Aceh Barat }\end{array}$ & $\begin{array}{l}15 \text { November } \\
2018\end{array}$ & $\begin{array}{l}\text { Tim } \\
\text { Pengab } \\
\text { dian } \\
\text { UTU }\end{array}$ & \\
\hline 4. & $\begin{array}{l}\text { FGD } \\
\text { Finalisasi DIP } \\
\text { Aceh Barat }\end{array}$ & $\begin{array}{l}16 \text { November } \\
2018\end{array}$ & $\begin{array}{l}\text { Tim } \\
\text { Pengab } \\
\text { dian } \\
\text { UTU }\end{array}$ & $\begin{array}{l}\text { Peserta Tim Pertimbangan PPID } \\
\text { Utama Aceh Barat (kegiatan } \\
\text { dilaksanakan sebelum Jumat) }\end{array}$ \\
\hline
\end{tabular}

Sumber: Diolah dari berbagai sumber, 2018.

Merujuk kesepakatan di atas, berbagai institusi yang terlibat dalam kerja sama memiliki peran dalam penyusunan daftar informasi publik. Selain itu, dalam pelaksanaannya juga melibatkan PPID Utama Aceh untuk menghadirkan sejumlah narasumber sesuai tahapan penyusunan daftar informasi publik. Berikutnya, tiap unsur yang terlibat dalam kemitraan memiliki arah tuju yang sama yakni lahirnya daftar informasi publik sebagaimana amanat UU KIP dan Perki SLIP. Selain itu, berbagai institusi juga memiliki peran tertentu dalam pelaksanaan kegiatan, misalnya PPID Utama Aceh Barat memastikan dukungan kebijakan, dana dan peserta dalam pelaksanaan workshop dan FGD. Sedangkan Tim Pengabdian UTU dan MaTA juga menyediakan dukungan dana dan narasumber selama pelaksanaan penyusunan daftar infromasi publik. Termasuk pula kesediaan PPID Utama Aceh dalam hal memastikan kehadiran narasumber yang sesuai dan ahli dalam penyusunan daftar infromasi publik.

Temuan lainnya bahwa selama pelaksanaan kegiatan memperoleh dukungan yang baik dari Pemerintah Kabupaten Aceh Barat. Dukungan yang penting dan strategis diperoleh pasca kegiatan focus group discussion (FGD) pertama yang dilaksanakan 
pada 9 November 2018. Merespons harapan PPID Utama Aceh Barat, Asisten I Pemkab Aceh Barat (Meurah Ali) memerintahkan Kepala Dinas Komunikasi dan Informatika selaku PPID Utama untuk melaksanakan pertemuan khusus antar pimpinan SKPK, dilaksanakan pada 12 November 2018. Selanjutnya, PPID Utama Kabupaten Aceh Barat melanjutkan agenda penyusunan daftar informasi yang dikecualikan yang dilaksanakan pada 3-5 Desember 2018. Workshop ini dilaksanakan selain selain kesepakatan awal di atas. Namun, karena dipandang penting untuk layanan informasi publik di Aceh Barat maka dilaksanakan dengan dukungan mitra lainnya.

Berdasarkan uraian di atas, jika merujuk pada pola kemitraan maka dapat dipastikan sesuai dengan pola kemitraan produktif. Pola ini menempatkan mitra sebagai subyek dan dalam paradigma commont interest. Prinsip simbiosis mutualisme sangat kental pada pola ini. Komponen OMS mempunyai kepedulian agar hak atas informasi publik dapat dipenuhi, pemerintah memberikan iklim yang kondusif bagi pemenuhan hak atas informasi dan didukung dengan peran perguruan tinggi.

Tujuan utama kemitraan antar institusi berkaitan dengan lahirnya daftar informasi publik. Masing-masing mitra memiliki peran dan fungsi sesuai kesepakatan sebelumnya. Jika digambarkan, model kemitraan yang terjadi dapat dilihat pada Gambar 11 sebagai berikut:

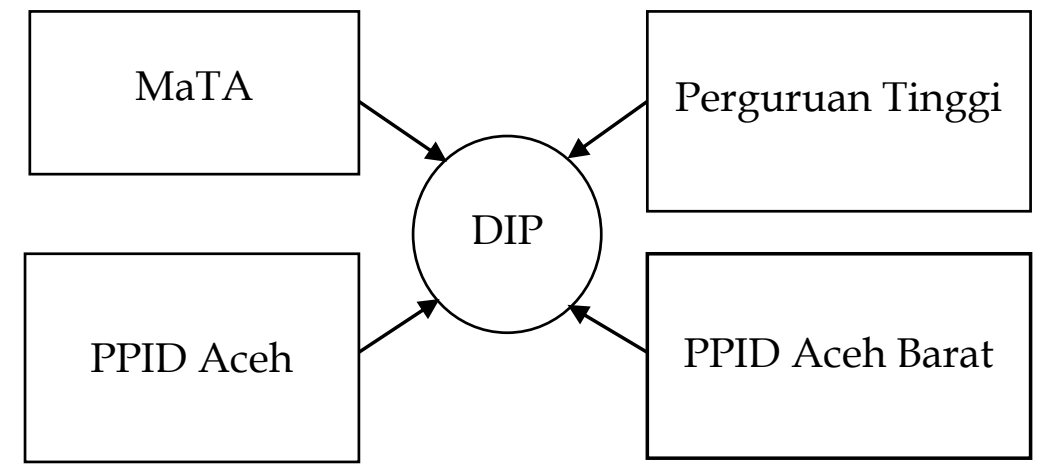

Sumber: Diolah Peneliti dari berbagai sumber

Gambar 11 Model Kemitraan Pengabdian

\section{Simpulan Dan Rekomendasi \\ Simpulan}

1. Pola kemitraan yang berlangsung adalah pola kemitraan produktif. Pola ini menempatkan mitra sebagai subyek dan dalam paradigma commont interest. Prinsip simbiosis mutualisme sangat kental pada pola ini. Komponen OMS mempunyai kepedulian agar hak atas informasi publik dapat dipenuhi, pemerintah memberikan iklim yang kondusif bagi pemenuhan hak atas informasi dan didukung dengan peran perguruan tinggi.

2. Proses koordinasi antara Tim Pertimbangan dan PPID Utama Kabupaten Aceh Barat menjadi penting dan strategis. Proses ini memberikan dukungan dan 


\section{JURNAL ABDIMAS BSI}

Jurnal Pengabdian Kepada Masyarakat

kemudahan bagi mitra untuk melaksanakan kesepakatan dan bahkan dilaksanakan kegiatan lainnya.

3. Proses pendampingan telah menghasilkan DIP PPID Utama dan PPID Pembantu di Kabupaten Aceh Barat, sesuai dengan Keputusan Bupati Aceh Barat Nomor 710 Tahun 2018 tentang Penetapan Daftar Informasi Publik Di Lingkungan Pemerintah Kabupaten Aceh Barat.

4. Adanya kerjasama antara perguruan tinggi, OMS (MaTA), PPID Utama Aceh, dan PPID Utama Kabupaten Aceh Barat semakin mempercepat proses penyusunan DIP

\section{Rekomendasi}

1. Perguruan Tinggi: Melanjutkan pendampingan untuk memastikan optimalisasi pelaksanaan UU KIP di Aceh Barat.

2. OMS (MaTA): Memastikan agar masyarakat dapat memperoleh haknya tentang informasi publik.

3. PPID Utama Aceh: Meningkatkan koordinasi dan komunikasi dengan PPID Utama Kabupaten Aceh Barat untuk optimalisasi pelaksanaan UU KIP.

4. PPID Utama Aceh Barat: Melaksanakan pemenuhan hak atas informasi publik melalui peningkatan koordinasi dengan Atasan PPID Utama serta PPID Pembantu di Kabupaten Aceh Barat.

\section{Daftar Pustaka}

Afrizal, T., \& Sudarman. (2017). Peningkatan Kepatuhan Badan Publik Dalam Pelaksanaan Undang-Undang Keterbukaan Informasi Publik Di Kabupaten Aceh Barat. Community, 3(1), 14-33. Retrieved from http://jurnal.utu.ac.id/jcommunity/article/view/143/133

Sulistyani, A. T. (2004). Kemitraan dan Model-Model Pemberdayaan. Yogyakarta: Graha Ilmu.

Wibisono, Y. (2007). Membedah Konsep E Aplikasi CSR (Corporate Social Responsibility). Jakarta: PT Gramedia.

Undang-Undang Nomor 32 Tahun 2004 Tentang Pemerintahan Daerah.

Undang-Undang Nomor 14 Tahun 2008 Tentang Keterbukaan Informasi Publik.

Peraturan Gubernur No 39 Tahun 2012 Tentang Pedoman Pengelolaan Informasi dan Dokumentasi Di Lingkungan Pemerintahan Aceh. 